\title{
From Grass Roots to World Class (A Strategy for Delivering Physical Activity)
}

\author{
Istvan Attila Kiraly, Andrea Gál
}

Semmelweis University Budapest, Hungary

ABSTRACT

During the 2008 Beijing Olympic Games, the Hungarian sports team's performance was worse than expected by most of the Hungarian people and the leaders of the Hungarian sports establishment. The Hungarian athletes returned home with a much lower medal tally than in previous decades. More than two years have elapsed since the Olympic Games, but instead of analysing the real reasons for the poor performance, most of the debates in Hungary are about whether we will restore our reputation by taking 8-10 gold medals in the 2012 London Olympics.

People in the United Kingdom are also full of hope for a great medal tally in London, not just because of the "home team advantage" but also by reason of the UK's outstanding performance in 2008. The British team finished fourth in the final medal table at the Beijing Olympic Games despite their poor performance one-and-half decades ago in Atlanta, surprising not just the British but also the whole world. By this time, the British strategy was to invest not just in elite sports but also in grass-roots participation sports. If Hungary wants to enhance its elite sports, it must engage in similar changes. It is clear from the latest data that the Hungarian XXI Sports Strategy's aim of making Hungary a sporting nation seems an illusion. Participation sports, which are the foundation of national sporting success and provide the future talents for the elite sports sector, are in need of urgent and substantive reform.

By means of secondary analyses and document analyses this article discusses the current state of British sport using the latest data. It then examines recent reforms in English participation sports as well as the latest sports strategy in England and its objectives. In all this, it makes comparison with what is happening in Hungary. The upshot is that Hungary and Britain differ at many points throughout the whole process, from strategy planning to implementation. These contrasts explain the differences in the effectiveness of the British and Hungarian processes. We hope that the outcome of this examination of the efficient Western European process and its comparison with the unsuccessful Hungarian system will assist those responsible for the development of participation sports and elite sports in Hungary.

KEYWORDS elite sports, participation sports, sports strategy, grass-roots participation sports

\section{Introduction}

More than two years have elapsed since the 2008 Beijing Olympic Games, where Hungary's performance was far below expectations. The Hungarian team finished twentieth in the final medal table with three gold, six silver and two bronze medals: the worst result since the 1924 Paris 
Olympics. The Hungarian press and electronic media discussed the background factors for what was considered both a fiasco and a realistic product of the current economic state of the nation. Most pointed to the financial issues as the cause of the problems in sports; other contributory factors mentioned were the lack of modern facilities, neglect of grass roots efforts, and the standard of medical care in sport. The Hungarian title of "sport power" had been lost and the humiliating outcome of the Olympics raised a great deal of concern about the prospects for elite sports in Hungary.

Meanwhile the major economic powers (China, USA, Russia, Great Britain, Germany and Australia) enjoyed an impressive success in the 2008 Games, collecting nearly $50 \%$ of the medals between them ${ }^{1}$. Amongst all of them, Great Britain surely created the greatest surprise, stunning the whole world by winning 19 gold, 13 silver and 15 bronze medals to take fourth place in the final medal table (In the Sydney 2000 and Athens 2004 Olympic Games, they won 11 and 9 gold medals respectively). In order to fully appreciate the success of the British athletes it is crucial to recall what happened one and a half decades ago. In the Atlanta Olympic Games in 1996, a single gold medal saved the honour of the British, won by the legendary Sir Steven Redgrave (already with three previous Olympic rowing golds to his name) and his partner Matthew Pinsent in the coxless pairs ${ }^{2}$. Britain had always been perceived as a "cradle of modern sports" and the 1996 debacle left the whole nation with a bitter taste. This situation proved an important warning to the British sports establishment and triggered the introduction of fundamental changes in the sports agenda. In previous decades, to ensure a return on the extensive investment in sport, rights for organising international 'mega sporting events' were won with remarkable diplomatic manoeuvres ${ }^{3}$. The UK economy at that time was robust enough to make the increased expenditure affordable. However, it was not only the extensive spending that formed the baseline of the recovery effort. The main emphasis was on the development of the participation and grass roots sports that underpin elite sports.

After the unsatisfactory performance at the Beijing Olympics, Hungary still lacks a fresh sports strategy that would target improvement in participation sports, which have always been under-funded and neglected when compared to elite sports. The stagnation in participation sports reduces the grass roots base in competitive sports, with negative consequences for future success in professional sport.

In this study, we attempt to compare the state of participation sports in Hungary and the UK by examining the most recent data on the sporting population as well as the relevant parts of the national sports strategies that were almost simultaneously declared in these two countries. The study uses secondary analyses and document analyses to answer the following questions:

1. What are the main efforts emphasised by the sports establishments in developing participation sports, and what targets are set for these in both countries?

2. What are the principal elements of participation sports development in English and Hungarian thinking, and how could they be practically achieved?

3. Could any changes be observed in the population's habits in participation sports? In other words, does the sports strategy work in Britain and in Hungary?

Looking at the history of sport, both countries have been involved in modern sports since their beginnings. However, taking into account the major differences in culture, democratic traditions, size, economic state and sporting traditions, this comparison has to be made with care. Certainly, the conclusions should offer some fresh ideas towards the development of participation sports.

\footnotetext{
${ }^{1}$ The top six nations in the medal table collected approximately 430 medals out of a total of 970.

${ }^{2}$ The British athletes collected 1 gold, 8 silver and 6 bronze medals overall in the Atlanta Games.

${ }^{3}$ Commonwealth Games: Manchester (2002), Glasgow (2014), UEFA Champions League final: Manchester (2003), London (2011), London Olympic Games (2012), Rugby League World Cup: England and Wales (2013), Rugby Union World Cup: England (2015), every year: Wimbledon, London Marathon and approximately 30-40 mega events in different sports. Source: UK Sport http://www.uksport.gov.uk/.
} 


\section{Terminology}

In the United Kingdom, some differences seem to have appeared in the terminology of participation sport, with slight distinctions in meanings. Public sports (sometimes called mass sports) - 'tömegsport' in Hungarian - refer to sports opportunities provided mainly by local authorities for the general public. In most cases participants engage in these sports activities at recreation grounds or leisure centres operated by local councils, e.g. jogging, cycling, swimming, various ball games, as well as different leisure sports activities such as badminton or informal competitions played occasionally. Community sports - 'közösségi sport' in Hungarian - characteristically mean sports activities organised mainly by local communities and voluntary sports clubs. In this case, the sports are organised by a small section of the local community. Community sports include most competitive sports performed in amateur leagues such as cricket, football or rugby, and leisure and recreation activities. The meaning of participation sports - similarly defined in Hungary - is based on the sports consumer's active participation in physical activity. On the other hand, passive consumers are those such as spectators who do not take part in sports activities themselves. There is a close relationship between the definitions of sport and recreation. Recreation originally meant 'to recreate' people's energy, health or spirit by relaxation or enjoyment; it can be extended to include sport. In this article, recreation sports are defined as those activities intended to restore people's health and their fitness for work, e.g. keep-fit, aerobics or spinning. Although this segment of participation sports does not necessarily involve a competitive element, it certainly necessitates regular activity. On the other hand, leisure sports are the kind of sports activities whose main motivation is entertainment and freedom; hence this category does not require regularity but does suppose competitive activity, e.g. beach volleyball or badminton. Social sports - "társasági sport" in Hungarian - are organised by small groups and communities for entertainment and socialising in teams, e.g. darts or rowing competitions. Sport for All frequently refers to participation sports in the international academic context, but in the United Kingdom it has been adopted for general use to mean exactly what it says, so it is likely to be applied to the promotion of a wider participation in sport, e.g. a free-swimming programme. There is a similarity with community sports, but with the slight difference that community sports embrace a smaller part of the community whereas Sport for All is applied to the whole society.

To give an exact definition of participation sports is not easy for Hungarian researchers either. On the one hand, difficulties arise from variations in methodology, targets for the different segments, and on the other hand because the general interpretation is being expanded by many relevant factors (Sárközy 2010). Significant changes in lifestyle ('modus vivendi') in the last few decades have also resulted in changes in sports. Nowadays some types of sporting activity do not require competition (e.g. jogging or keep-fit), while the competitive element enters into sporting activities not requiring physical activity (e.g. bridge or chess). As the recreational (in the sense used in this article) aims of sports have become more prominent, several new sporting activities have appeared (e.g. spinning or aerobics); these emphasize less the performance aspects and more the beneficial effects of health and well-being. Some segments of participation sports, e.g. badminton in a park, beach football or beach volleyball, are primarily played not for reasons of health or recreation, but rather for pure enjoyment; the motivation is not to maintain or restore fitness for work, or health. The definition of participation sports is being broadened to include activities designed for specific groups, such as the elderly, children or students, and technical sports such as hang gliding, Wii, parachuting or waterskiing. However, we have to attempt a definition, and in Hungary the mainstream terms used are participant sport, recreation sport or the currently fashionable 'Sport for All'. It is not generally realised that 'Sport for All' is used as an umbrella term for recreation, mass participation and multicultural recreation activities; all these aim to improve the quality of leisure activities, and health (Da CostaMiragaya 2002). Earlier researchers measured conventional sports practices but today they measure a widening spectrum of physical activities such as walking, hiking, cycling as a means of transport, dancing and gardening. 


\section{Habits in recreation and sports activities in Great Britain and Hungary}

To analyse British recreational and sports habits we first have to look back a few years to the joint DCMS/Strategy Unit Report (Game Plan: A Strategy for Delivering Government's Sport and Physical Activity Objectives), published in December 2002. It was a comprehensive study of the state of the different segments of British sports and gave data about the actual recreational and sporting habits of the entire British nation.

In 2002, the report indicated, only $18 \%$ of the British population participated in sports intensively, $10 \%$ participated regularly, and $72 \%$ participated occasionally, rarely or not at all $1^{4}$. If some moderate physical activities (e.g. walking with moderate intensity for a minimum of 30 minutes) were included, $32 \%$ of the population engaged in sports at least five times a week. Young males were most likely to take part in sports and physical activities, and the most disadvantaged groups were the least likely. Participation fell dramatically after leaving education, and continued to drop with age. But those who were more active in sports and physical activities at a young age were more likely to continue to participate throughout their lives. People with higher educational qualifications, managers, skilled workers and professionals took part in sports more than others. For most sports and physical activities, participation was $19 \%$ higher among men, with swimming and keep-fit/yoga the only notable exceptions. However, women with higher qualifications were more active than men with the same educational background. Generally, individuals from low socio-economic categories had a low participation level in sports and physical activities, which may have contributed to their poorer health and mortality rates compared to other groups. For ethnic and minority groups overall, the participation rates in sports were $6 \%$ lower than the national average; the greatest disparity was in the Midlands, the area with one of the largest Muslim communities in the country ${ }^{5}$. In the period examined, the most popular recreational and physical activities in the UK were jogging, swimming, cycling, golf, tennis, squash, badminton, and walking ${ }^{6}$. Some sports and physical activities, e.g. football, cricket, softball and rugby, were preferred by men while others, e.g. keep-fit, aerobics, yoga and dancing, were more popular with women.

In Britain, it was generally considered that in order to improve the sports culture of the nation as a whole, it would first be necessary to increase the number of participants in sports and physical activities. Hence the main thrust of the DCMS strategy was to widen the appeal of public sports; in other words, to significantly raise the number of participants. Furthermore, it emphasised that one of the major objectives of participation sports is to improve social values, which in turn enhances other positive functions of sports, e.g. health, entertainment and social benefits. The British strategy also highlighted the positive changes with respect to participation sports that may also cause positive shifts in elite sports. At the same time they were implementing the sports strategy, the British introduced a new monitoring system which would accurately follow changes in the number and profile of sports participants, and the results of the targeted programmes. With this information, it was possible to monitor the effectiveness of the implementation and to make any necessary adjustments. The DCMS strategy and many shorter-term programmes, e.g. Sport England Strategy 2008-2011, have achieved appreciable results in a short time. These will be discussed later in this study.

In Hungary, participation sports have always remained in the shadow of elite sports. Although Hungary still prospers in elite sports, three-quarters of the population rarely or never take part in sports. This is one reason for the poor health and high mortality rates amongst a significant part of the Hungarian population. Earlier research data (e.g. Időmérleg 1999-2000 research) indicates that only $29.7 \%$ of the Hungarian population take part in any sort of physical activity: not, however, with any regularity (Gáldi 2004). Another study (Ifjuság 2004 research) demonstrated a high proportion of

\footnotetext{
${ }^{4}$ Intense $>120$ times/year, regular $>60<120$ times a year, occasional and rare $<60$ times a year.

${ }^{5}$ Source: DCMS / Strategy Unit Report (2002), pp. 21-28.

${ }^{6}$ Walking defined as a minimum 30 minutes intensive walking regularly, as a recreational exercise.
} 
inactive people amongst the young. In people ranging from the ages of 15-29 years old, only $41 \%$ regularly do sports in their leisure time. Both studies reveal a great divide between the active and the inactive. In Hungary, as in Britain, the young, the males, those still in education, town-dwellers, and people with higher education are more likely to take part in sport than working people and countrydwellers. In addition, a vital conclusion of the studies is that the financial state of households has a serious effect on their interest in physical activity. People in a state of poverty are much less likely to participate in any physical activity than those with a high standard of living.

The quality and quantity of participation in sports and physical activities in Hungary are much lower than in other European countries ${ }^{7}$, and these levels have not significantly changed over recent years (Sport XXI National Strategy, p. 4). The International Social Survey Programme (ISSP) 2007 reported that $26 \%$ of the Hungarian population were active every day if walking and hiking were included. In provincial cities, greater rates of highly educated people and, surprisingly, women show interest in physical activity. While sport is popular with young people, walking and hiking are more typical of the elderly. (In Hungary as in Britain, people are less likely to take part in sport after they have left education.) According to the survey's respondents, the most frequent locations for sport and physical activity were the home, municipal parks and swimming pools. The most frequent forms of sport were aerobics, weight training, body conditioning, cycling, swimming and a wide variety of gymnastics. All team sports except football are struggling, understandably because it is not easy nowadays to bring people together into teams and to organise appropriate places for friendly matches (Gál 2008).

The results of the research warn sports proponents that ten years into the new millennium, we have not been able to improve the nation's sporting habits. In fact, no positive trend could be observed at all. In the meantime, it is now obvious that we cannot postpone action any longer because projected Hungarian mortality and morbidity rates point to looming serious economic and social problems. A well-structured, long-term sports strategy has become necessary to address the problems in sports politics, but with the main aim of improving participation sports.

\section{Three-year prospects for performance and efficiency}

The English sports strategy was developed by Sport England in 2008 in order to focus on a shorter time period than the DCMS / Strategy Unit "Game Plan" of $2002^{8}$. The primary aim of the former was to develop a world-leading community sports system that supported the nation's health policy and to provide a strong base for many segments of sport such as elite sports.

\section{Sport England Strategy (2008-2011)}

As highlighted earlier, after investigating the state of several segments of British sport, the DCMS / Strategy Unit Report focused creating a holistic, long-term reform of sport over a period of 20-25 years. The document suggested that to improve national performance it was necessary first to define different categories of sports. The highest priority sports were the traditional British and English sports, and sports in need of improvement ${ }^{9}$. These $30-40$ sports received focused attention and additional investment compared to other sports. To ensure a return on the extensive investment, the

\footnotetext{
${ }^{7}$ However, among the Eastern European countries, Hungary is placed in a medial position in sports and physical activities.

${ }^{8}$ Sport England (formerly the English Sports Council) is a non-departmental public body accountable to the Department for Culture, Media and Sports. Its role is to build the foundation of a community sports system by working with national sports governing bodies and other partners.

${ }^{9}$ Traditional British sports included athletics, kayaking, canoeing, sailing, rowing and swimming. Traditional English sports included golf, badminton, netball, softball, rugby, squash, tennis and cricket. Sports in need of improvement included basketball, volleyball, karate, boxing and table tennis.
} 
British won the rights to host many 'mega sporting events' which gave an economic boost not just to sport but also to the whole British economy. The report also recommended organisational reform to improve delivery, reduce bureaucracy and ensure that more money reached sports. The delivery capacity of key organisations, in both the public sector and the governing bodies, needed to be increased in the interests of consumers. The DCMS / Strategy Unit Report was followed by many shorter-term strategies whose aims dovetailed into the main programme.

Table 1. Sport and active recreation participation (at least once in the last four weeks)

\begin{tabular}{|c|c|c|c|c|c|c|c|}
\hline \multirow[t]{2}{*}{ Active People Survey (APS) } & \multicolumn{2}{|c|}{ APS $1(2005 / 06)$} & \multicolumn{2}{|c|}{ APS $2(2007 / 08)$} & \multicolumn{2}{|c|}{ Change } & \multirow{2}{*}{$\begin{array}{c}\text { Statistically } \\
\text { significant } \\
\text { change }\end{array}$} \\
\hline & $\%$ & number & $\%$ & number & $\begin{array}{l}\text { in } \\
\%\end{array}$ & $\begin{array}{l}\text { in } \\
\text { number }\end{array}$ & \\
\hline Walking (moderate intensity) & $20.0 \%$ & 8142200 & $22.0 \%$ & 9096900 & $1.95 \%$ & 954700 & Yes \\
\hline Swimming (all) & $13.8 \%$ & 5633700 & $13.4 \%$ & 5570100 & $-0.40 \%$ & -63600 & Yes \\
\hline Gym & $10.5 \%$ & 4266300 & $10.7 \%$ & 4448200 & $0.26 \%$ & 181900 & Yes \\
\hline Cycling (moderate intensity) & $7.8 \%$ & 3175500 & $8.5 \%$ & 3510200 & $0.67 \%$ & 334700 & Yes \\
\hline Football & $7.1 \%$ & 2910600 & $7.6 \%$ & 3142300 & $0.43 \%$ & 231700 & Yes \\
\hline Athletics (all) & $5.0 \%$ & 2043700 & $6.0 \%$ & 2503700 & $1.02 \%$ & 460000 & Yes \\
\hline Golf & $3.6 \%$ & 1457300 & $3.7 \%$ & 1544100 & $0.15 \%$ & 86800 & Yes \\
\hline Tennis & $2.1 \%$ & 874000 & $2.3 \%$ & 939500 & $0.12 \%$ & 65500 & Yes \\
\hline Badminton & $2.2 \%$ & 900300 & $2.3 \%$ & 939500 & $0.06 \%$ & 39200 & No \\
\hline Aerobics & $1.5 \%$ & 608700 & $1.6 \%$ & 658000 & $0.09 \%$ & 49300 & Yes \\
\hline Yoga & $1.4 \%$ & 559300 & $1.4 \%$ & 600700 & $0.08 \%$ & 41400 & Yes \\
\hline Ex Bike/Ex Machine/ Spinning & $1.2 \%$ & 510200 & $1.4 \%$ & 589500 & $0.19 \%$ & 88300 & Yes \\
\hline Squash & $1.2 \%$ & 500700 & $1.2 \%$ & 486200 & $-0.06 \%$ & -14500 & No \\
\hline Weight Training & $1.0 \%$ & 394000 & $1.1 \%$ & 459000 & $0.14 \%$ & 65000 & Yes \\
\hline Cricket & $0.9 \%$ & 380400 & $1.0 \%$ & 429600 & $0.08 \%$ & 39200 & Yes \\
\hline Basketball & $0.7 \%$ & 275100 & $0.8 \%$ & 330100 & $0.12 \%$ & 55000 & No \\
\hline Dance Exercise & $0.5 \%$ & 204800 & $0.5 \%$ & 203300 & $-0.01 \%$ & -1500 & No \\
\hline Darts & $0.3 \%$ & 119900 & $0.3 \%$ & 106200 & $-0.04 \%$ & -13700 & Yes \\
\hline Volleyball & $0.2 \%$ & 68600 & $0.2 \%$ & 86400 & $0.04 \%$ & 17800 & Yes \\
\hline
\end{tabular}

Source: Sport England: Active People Survey 2007/08.

With the Olympics and Paralympics due to come to London, the leaders of the British sports establishment considered that it was an appropriate time to take a good look at the sports structure which had been under development for almost six years by then. Therefore, in December 2007 the Secretary of State for Culture, Media and Sport asked Sport England to review its strategy for community sports in England. Consulting with over 100 stakeholders from across the sport sector, Sport England developed a new strategy for community sports for the period 2008-2011 using the experiences of the last decade ${ }^{10}$. The achievements clearly confirmed that the strategy was working: in the most popular sports and recreational activities alone, e.g. walking, jogging, running, cycling, keepfit/yoga, tennis and badminton, the number of participants had risen by two million (Table 1). The Active People Survey, which ran from October 2005, measured participation over 250 sports and recreational activities ${ }^{11}$. The document indicated that the number of participants in approximately 40 sports had grown significantly in the previous three years. In Table 1, it can be seen that walking was the most popular recreational activity in the period examined. In $2007 / 8$, over 9 million adults $(22 \%)$ went for a recreational walk of at least 30 minutes in a 4 -week period. This represents an increase of 954700 participants (from 8.1 million in 2005/6). The table indicates that cycling participation grew

\footnotetext{
${ }^{10}$ The key delivery partners of Sport England were: National Governing Bodies (NGBs), National Partners, Local Authorities and County Sports Partnerships, Schools and School Sports Partnerships, Higher Education Institutions, Third Sector organisations, community sports organisations and commercial organisations.

${ }^{11}$ Active People Survey is a national sports participation survey of adults (age 16 and over) in England carried out by Ipsos MORI on behalf of Sport England. The first year of the survey (Active People Survey 1) was completed between mid-October 2005 and mid-October 2006, and Active People Survey 2 was undertaken between October 2007 and mid-October 2008. Ipsos MORI were contracted to collect data until October 2010 (completing Active Surveys 3 and 4).
} 
from 3.18 million adults (7.8\%) to 3.51 million adults $(8.5 \%)$, an increase of 335,000 participants. Football participation (indoor and outdoor) went up from 2.91 million adults (7.1\%) to 3.12 million adults (7.6\%), an increase of 232000 participants. In most sports activities, e.g. golf, gym or athletics, significant growth can be observed; meanwhile some sports and physical activities, e.g. swimming, squash, darts and dance exercises, declined in terms of the number of participants.

\section{Vision and outcomes}

The strategy focused on the three-year period 2008-11. However, in some cases it was also extended to 2012-13, because some targets were linked to the London Olympic Games and because of the significant role of the National Governing Bodies' 2008-13 funding round. The strategy's priority was to address the fundamental challenges facing community sports, in particular (Sport England Strategy 2008. p. 5):

- "Increasing participation in sport",

- "Tackling drop-off". Thousands of people drop out of playing sports each year. This problem was particularly recognised at the age of 16 , where 25000 stopped playing sports each year ${ }^{12}$,

- "Developing talent". As England has always had a successful medal record at the elite level, the strategy aimed at maintaining the pipeline of talent feeding elite sports.

The report clarified the roles of the key sports bodies. School sports were the responsibility of the Youth Sport Trust while Sport England's focus was on the recruitment of school dropouts into community sports ${ }^{13}$. The responsibility for elite sports rested with UK Sport ${ }^{14}$. Sport England played a critical part by working with the NGBs (National Governing Bodies) to ensure that the talent system was linked with elite programmes.

The strategy set the following measurable targets, as quoted from the report (Sport England Strategy 2008, p. 9):

- "1 million people doing more sport by 2012-13,

- a reduction in post-16 drop-off in at least five sports by $25 \%$ by $2012-13$,

- a quantifiable increase in satisfaction (actual measure to be determined) ${ }^{15}$,

- improved talent development system in at least 25 sports,

- a major contribution to the delivery of the Five Hour Sport Offer engaging more 5-19 year olds in sport" $" 16$.

The strategy defined that Sport England had the specific role to (Sport England Strategy 2008, p. 12):

- "act as an advocate for community sport with national, regional and local government,

- enable the delivery of community sport by creating partnerships,

- invest in community sport through our partners,

- influence policy and decision-making through high quality research and by identifying best practices both here and abroad.

\footnotetext{
${ }^{12}$ In the United Kingdom, education is compulsory up to age 16, after which sports are not mandatory.

${ }^{13}$ The Youth Sport Trust is a British charitable trust, which aims to support the education and development of young people through physical education.

${ }^{14}$ UK Sport is the UK Government's organisation for directing the development of sport in the UK. It is a nondepartmental public body established in 1997 by Royal Charter and accountable to the Department for Culture, Media and Sport.

15 "The existing satisfaction baseline from Active People provides information about the provision of sport in an area. A new baseline will be developed in the first half of 2008-09 which will ascertain participants' satisfaction with the quality of their experience." (Sport England Strategy 2008, p. 9)

${ }^{16}$ Physical Education and Sport Strategy for Young People (PESSYP) is often referred to as the 5 Hour Offer. By 2011, the ambition outlined in the strategy was to offer all children at least five hours of sport every week.
} 
- hold our funded partners accountable for the delivery of results".

It is also important to highlight the economic logic of the strategy. The satisfaction level of the consumer demands a high standard of excellence, enhances the attraction and satisfaction of the sport consumer, and results in a huge increase in demand. According to the classic economic approach, the growth of demand triggers an automatic rise in the price of sports services, in turn encouraging competition amongst sports suppliers in the voluntary, private and government sectors. The rivalry between the different parties also enhances the quality of services, further increasing the satisfaction level and the extent of demand.

The strategy set out three catchwords: Excel, Sustain and Grow.

Excel, with $25 \%$ of Sport England's investment, focused on fast-tracking talent into elite programmes, with responsibility for achieving well-defined targets allocated mainly to the NGBs. Emphasis was placed on founding appropriate talent systems for different sports and delivering appropriate coaching provisions.

Table 2. Sport England Strategy: key programmes and results

\begin{tabular}{|c|c|}
\hline Priority areas & Performance measures \\
\hline $\begin{array}{l}\text { National Governing Bodies } \\
\text { and National Partners }\end{array}$ & $\begin{array}{l}\text { NGB 2005-09 Whole Sport Plan targets achieved } \\
\text { NGB 2009-13 funding process completed } \\
\text { Relationship with National Partners reviewed; } \\
\text { Playground-To-Podium launched }\end{array}$ \\
\hline Clubs and Coaches & $\begin{array}{l}\text { Community Sport Coach Scheme targets achieved } \\
\text { Club and Coach Fund targets achieved } \\
\text { Agree Coaching for Young People strand of PESSYP with YST and } \\
\text { Government }\end{array}$ \\
\hline Children and Young People & $\begin{array}{l}\text { Extending Activities targets around young people attending } 60 \% \text { of weekly } \\
\text { sessions achieved } \\
\text { Step into Sport targets regarding percentage of young people aged 14-19 and } \\
11-19 \text { from School Sport Partnerships actively involved in leadership and } \\
\text { volunteering achieved } \\
73500 \text { young people access Sport Leaders UK courses } \\
\text { Club Links targets on 5-16 year olds participating in NGB-accredited clubs } \\
\text { achieved } \\
\text { Clubmark targets achieved }\end{array}$ \\
\hline Regional / Sub-Regional & $\begin{array}{l}\text { Agree core functions for County Sport Partnerships aligned partners to NGB } \\
2009-13 \text { funding }\end{array}$ \\
\hline Local Government & At least 75 Local Authorities signed up for NI8 in their Local Area Agreement \\
\hline $\begin{array}{l}\text { Strategic Planning and } \\
\text { Facilities }\end{array}$ & $\begin{array}{l}27 \text { Local Authorities engaged successfully by Facilities Improvement Service } \\
\text { Targets regarding investment secured for community sport through planning } \\
\text { system achieved }\end{array}$ \\
\hline Grants Managements & $\begin{array}{l}\text { Consultation on Lottery funding completed } \\
\text { Funding streams transitioned into the 'single-pot' } \\
\text { Development of a simplified, single-application process for grants recipients }\end{array}$ \\
\hline Commercial development & $\begin{array}{l}£ 3 \text { million of commercial support raised }(2008-09) \\
£ 4 \text { million }(2009-2010) \\
£ 8 \text { million }(2010-11) \\
£ 10 \text { million }(2011-12)\end{array}$ \\
\hline $\begin{array}{l}\text { Business Planning and } \\
\text { Performance Management }\end{array}$ & $\begin{array}{l}\text { New strategy successfully launched } \\
\text { Progress and performance reported quarterly to DCMS }\end{array}$ \\
\hline Communications & New Stakeholder Survey created \\
\hline Efficiency Programme & Agreed reduction in operating costs to be achieved \\
\hline Organisational Structure & New structure in place by end of Q3 2008-09 \\
\hline
\end{tabular}


Sustain, with $60 \%$ of Sport England's investment, focused on reducing drop-off from sports in the 16-18 year-old age range. Emphasis was placed on participants' satisfaction with the quality of their experience. By reducing drop-off by $25 \%$ in at least five sports, they could subsequently disseminate the lessons learned across other sports in the 2011-14 timeframe.

Grow, with 15\% of Sport England's investment, focused on increasing regular participation in sports by both youngsters and adults. The target for adults was to have 1 million people doing more sport by 2012-13, with a 25\% contingency added to allow for different success rates. A goal shared with the Youth Sport Trust was to improve access for young people by five hours of sport a week; the target set was a 33\% participation rate amongst 5-16 year-olds in NGB-accredited clubs by 2010.

As the table shows, the identification of the priority areas of the strategy was comprehensive. It encompassed many different contributors, such as organisations, facilities, coaching providers and funding sources. The financial plan gave a year-by-year breakdown of its elements.

\section{The present and future of Hungarian sports: The XXI National Sports Strategy}

The XXI National Sports Strategy, with its vision for different areas of sports up to 2020, was accepted in June 2007. After a general situation analysis, it proposes aims for sports policy, the direction for innovation in certain areas of sport, and implementation concepts up to 2013. It states that the development of the main sectors of sport is dependent on a reform of their financing, because the Hungarian system differs from the successful models of the EU countries. Lottery, broadcasting rights and private finance, though currently minor sources of funding, could take the place of the public sector. Likewise, the lack of sports facilities and the dilapidated state of the existing ones should receive attention. In addition, the document highlights innovation in specialists' training and the need for more effective involvement of sports science. The authors of the Strategy formulated a vision of participation sports so that Hungary, in addition to involving a wider range of the population in sports to maintain its reputation as a 'Sports Nation', could become a 'Sporting Nation' within a reasonable time. "So the aim is to engage people successfully in sport as a part of their lifestyle, thus improving Hungarians' health and quality of life. Sport should help improve social and family relationships, cut unemployment, increase productivity and reduce social inequality" (Sport XXI Nemzeti Sportstratégia, p. 5).

The Strategy deals rather superficially with the state of participation sports and the reasons behind its weaknesses (although the lack of sports facilities and household financial problems are mentioned), but no details are given about the demographic profile of regular exercise and the background factors to the absence of sport from people's lifestyles. Without the empirical assessment of these issues, however, it is extremely difficult to develop ideas which will in practice be successful in encouraging greater physical activity among the population. Similarly, there was no measurement of the number of people taking part in participation sports or indeed in other sectors of sport. According to the SWOT analysis found in the Strategy, the realisation of the 'Sporting Nation' is jeopardised by a lack of resources and strained economic circumstances, the inadequate cooperation of voluntary sectors and the underdevelopment of the leisure industry. The following are mentioned amongst the general strategic targets of sports policy: improved quality of life; development of a healthier society; extended networking within sports and between sports and society; national and community identity; social cohesion; enhanced competitiveness and increased employment; and promoting equal opportunities. 
Figure 1 shows the priority areas of participation sports and the most important tasks relating to them.

\begin{tabular}{|c|}
\hline INDIVIDUALS, FAMILIES \\
Paradigm shift \\
Motivation \\
Self-interest \\
Freedom of choice \\
\hline
\end{tabular}

\section{SPORTS BUSINESSES}

Increase supply

Economic interest

Quality of service

Media exposure

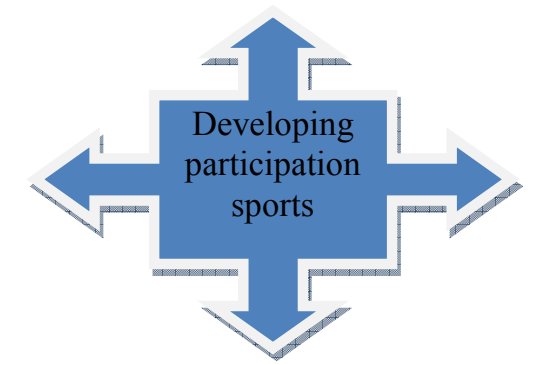

CIVIL ORGANISATIONS, LOCAL COMMUNITIES

Paradigm shift

Self-interest

Recognition and support Information system

\section{GOVERNMENT SECTOR, LOCAL AUTHORITIES \\ Increase supply \\ Programme subvention \\ Inspire private sector investment \\ Extra assistance to \\ disadvantaged groups \\ Indirect financial incentives}

Figure 1. The most significant factors in the development of participation sports

Source: Based on XXI. Hungarian National Sport Strategy.

It can be seen that the development of participation sports is highly reliant on local authorities, so the accomplishment of tasks depends fundamentally on their fulfilling their obligations. As Rezsö Gallov wrote, "Instead of direct government subsidy, the central facilitation of the strategy is seen in terms of communication and indirect economic factors such as the economy itself and taxation policy" (Gallov 2007, p. 45). However, the most important challenge at the level of the individual, the family and the local community is to encourage positive attitudes towards sport that will generate rising demand.

\section{Comparison of strategies}

In order to make a comparison between the English and Hungarian strategies, recent historical background needs to be outlined. The year 2002 saw the development of the British participation sports strategy that provided the foundation for the Sport England strategy; it was announced in 2008 and put into immediate effect. The strategy was planned on the basis of a thorough sport sector analysis conducted beforehand.

In Hungary, the intention to improve participation sports was declared on several occasions, but setting effective targets and identifying the means to achieve them was not undertaken. The National Leisure Sports Federation (NSZSZ) did not approve a draft concept that incorporated the vision of a united 'Sports Nation' and sporting nation, which had been formulated at the end of $2004^{17}$. The government later rejected it, as it lacked financial guarantees. In 2005, despite the government's tacit

\footnotetext{
${ }^{17}$ National Leisure Sports Federation (Nemzeti Szabadidősport Szövetség: NSZSZ) was established in 2001. Its role is to organise participation sports in Hungary working with other partners from different areas, e.g. youth sports, schools, higher education and sports for people with disabilities.
} 
approval, the strategy project was not submitted to Parliament and it was effectively shelved. Susceptibility to political influence also caused considerable damage to Hungarian sport. The key decisions on previous strategies were made by the political powers of the day, regardless of any criticism. As a government advisory body, the National Sports Council (NS) lacks the authority to enforce regulations and therefore fails to protect the interests of participation sports ${ }^{18}$. Political lobbying remains the sole option. By contrast, the NS's counterpart, the independent and autonomous Sport England, makes the elimination of political influence one of its key objectives. In a further contrast, Britain's main strategy is underpinned by several short-term plans while Hungary's sole programme defines targets for the subsequent 20 years. With enough time to implement the desired changes, the long-term strategy may be successful, provided political influence is kept out. However, political interference is always a risk because of unpredictable events such as the global economic crisis. The design of a financial model for sport must take into account the changes that have been happening in recent decades such as the increasing effects of globalisation and the transformation of sport into an industry. In England, the development of participation and elite sports is tackled on local, regional and national levels while problems that arise are interpreted in a global context.

As pointed out earlier, the main idea of the English sports strategy is to expand the number of participants. Its implementation depends on schools and other educational institutions becoming the key players, as grass roots efforts form the foundation of both participation and elite sports. It is crucial for sports education to be aligned with the aims and concepts of participation and elite sports policy. It is also essential that collaboration between schools, participation sports, and voluntary sports clubs be encouraged. Growth of sporting activity within the nation and the related improvement of health indicators rely on developing a series of direct incentives coming from corporations, insurance companies and central and local government, all of which will stimulate the demand for sport. However, in order to achieve a sizeable increase in participation, it is essential to develop a positive attitude towards sport throughout the nation. This task needs to be addressed from two angles. First, it is necessary to segment potential participants into different consumer groups and deliver the relevant information on the benefits of sport, i.e. social, individual, leisure and recreation, and on how to access the sporting opportunities. At the same time, it is necessary to provide financial incentives such as tax discounts or tax allowances to make it possible for more social groups to get involved.

The realisation of these proposals depends on drawing up a comprehensive marketing strategy that would allow information to be distributed to relevant consumer groups and other stakeholders (insurance companies, businesses, and health institutions) through both mass media and direct communication through doctors, teachers and coaches. Failure to develop such a marketing strategy will weaken the chances of the targets being achieved. Unlike England's approach, the Hungarian sports strategy is general and vague, leaving the bodies responsible for its implementation lacking clear guidelines. Although the idea of cooperation between different areas of sport exists in Hungary too, the strategy has not transformed this model into concrete results. For the present, the only hope for Hungarians is that the government, local authorities, voluntary organisations and business will adopt united approaches in the future, which may effectively improve the whole sports sector.

From an economic viewpoint, the supply side of sport comprises the public, voluntary and private sectors. As each party plays a different role in the supply side, they have different targets and involvements in sport (Király 2010). Therefore, the supply side of sport cannot be fulfilled by only one party, whether the government or the private sector; it requires the contributions of all suppliers. While the English methodology focuses on stimulating the demand for sport, the Hungarian one focuses on developing the supply side. It is crucial to emphasise the significance of the funding issue, since financial difficulties were the main reason for the failure of the sports strategy in Hungary. Despite the formation of several sports associations under the umbrella of the NSZSZ, lobbying for increased

\footnotetext{
${ }^{18}$ National Sports Council (Nemzeti Sporttanács: NS) a governmental advisory body established in 2004 and ceasing to exist in 2010 .
} 
government sport-related funding for participation sports has proved unsuccessful. In England, the financial resources management provides the sports establishment with a transparent funding system incorporating distribution channels used by public and private sector alike. It may be asked how the global economic crisis affects the financial side of sport in the UK. In Hungary, the need to reduce operating costs, to 'tighten the belt', puts many small businesses off ideas such as 'sports days'. As a result, participation and elite sports in Hungary have lost a group of potential supporters and sponsors long before they could actually be recruited. Another financial issue is that, unlike in Hungary, a significant proportion of the entire English sports funding is obtained through National Lottery revenues. Implementing this idea would provide a well-planned, politically independent and relatively stable income for sport in Hungary as well.

The stimulus for the strategic plans in both countries was the same: the need to reorganise the institutional structure of sport. In the two decades since the political and economic transition in Hungary occurred, there have been many attempts to change institutions and organisations, although the efforts appear to be more for show than results. It is obvious, however, that given the size and population of the country, sports institutions in Hungary display a fragmented structure, resulting in operational costs being exceptionally high and proportionally higher than in Western European states. Instead of cooperating, the numerous sports organisations established in the last twenty years work in parallel, leading to less than optimal efficiency. The effectiveness of the sports strategy has been jeopardised by the lack of operational programmes; their development, however, depends on identifying the socio-economic categories to be addressed.

The English sports strategy concentrates on reducing the drop-off amongst the over-sixteens after they leave school. Local community programmes not only benefit participation sports but also discover talent for elite sports and increase the number of voluntary sports club members. The Hungarian scheme, on the other hand, treats the participants in participation sport as a homogeneous whole despite the fact that many sociological research studies have singled out several subgroups and described their demographic and economic characteristics. In fact, it is foolhardy to overlook these sociological aspects because the rich-poor divide has multiplied in Hungary since the political and economic transition. It is not realistic to expect demand for sport to grow in financially and culturally impoverished groups, who have fallen behind even in 'passive sports consumption', for instance, as spectators or media consumers. Nevertheless, the sports establishment must not abandon these groups. They should be targeted with special and well-organised programmes to enhance their chances of getting involved in sports and physical activities.

In the UK - as in other Western European countries - the voluntary sector plays a significant role in running participation sports. In England in 2005, there were 1.9 million volunteers in sport, equivalent to approximately 80000 full time workers in terms of their added value ${ }^{19}$. The Sport England Strategy aimed to add 8000 volunteers on the supply side, mainly in coaching and other educational activities. In Hungary, this kind of voluntary activity seems a pipe dream, even though there are a large number of retired people who should be galvanised into passing on their knowledge and experience to the young.

Finally, it is essential to mention the implementation of the new monitoring system successfully introduced by the British. This system precisely tracks the changes in the number and profile of sports participants, as well as the results of the targeted programmes. With this information, it is possible to monitor their effectiveness and to make necessary adjustments. Hungary has no such monitoring system. Its lack makes it more difficult to monitor the whole strategy and the implementation of the related sports plans. The only feedback comes from some scientific groups, market research companies and national surveys. However, these bodies use different methodologies in their studies, which make it complicated to use the data to analyse trends. There already exists an international

\footnotetext{
${ }^{19}$ Volunteer in sport for at least an hour each week. Sources: (Sport England Strategy 2008-11, p. 3).
} 
survey in the EU, which gives a comprehensive view of each EU country's sporting habits and the direction of their sports policies.

\section{The evidence for the demand for sport}

Eurobarometer is a series of surveys regularly conducted on behalf of the European Commission since 1973. Eurobarometer launched a new representative study in 2009, which monitors the sporting activity in the population of 27 European countries. The study covered not only 'traditional' sports, but also other physical activities like walking, cycling for transport, gardening and dance-based activities. The study indicates that $14 \%$ of the British population take part in sports intensively while only $5 \%$ of Hungarians do sports at least five times a week (EU average $=9 \%$ ). The study also shows that whilst $32 \%$ of the British take part in some kind of physical activities occasionally, only $18 \%$ of Hungarians do so $(\mathrm{EU}$ average $=31 \%)$. In terms of gender, British participation in sports is much higher among males than females - particularly in the 15-24 age range - but in Hungary there is low sporting activity in both males and females.

Table 3. The proportion of regular sporting and physical activities (at least five times a week) in the UK, Hungary and EU27

\begin{tabular}{lcccc}
\hline & & UK & HU & EU27 \\
\hline Overall & & $14 \%$ & $5 \%$ & $9 \%$ \\
Gender/ Age & & & & \\
\hline \multirow{3}{*}{ Male } & $15-24$ & $34 \%$ & $11 \%$ & $19 \%$ \\
& $25-29$ & $13 \%$ & $5 \%$ & $9 \%$ \\
& $40-54$ & $15 \%$ & $2 \%$ & $7 \%$ \\
& $55-69$ & $18 \%$ & $3 \%$ & $10 \%$ \\
Female & $70+$ & $14 \%$ & $1 \%$ & $8 \%$ \\
& $15-24$ & $6 \%$ & $6 \%$ & $8 \%$ \\
& $25-29$ & $9 \%$ & $5 \%$ & $7 \%$ \\
& $40-54$ & $12 \%$ & $4 \%$ & $10 \%$ \\
& $55-69$ & $17 \%$ & $5 \%$ & $11 \%$ \\
\hline
\end{tabular}

Source: Eurobarometer (2009) http://www.ec.europa.eu.

Furthermore, in Britain only $32 \%$ of the population never take part in any sport or physical activity while in Hungary $53 \%$ of the population are inactive (EU average $=50 \%$ ). Eurobarometer also emphasises that people in poverty are less likely to get involved in participation sports (or are more likely to be crowded out of participation sports) than those with a higher standard of living.

According to new research, the disparity has become ingrained not only in sports participation, but also in 'passive sports consumption' like visiting sporting events, and 'buying' sports through the media (reading papers, listening to the radio, etc.) (Földesiné 2008). However, the participation levels in other physical activities, e.g. walking and cycling for transport, gardening and dance activities, are higher in both countries: Britain $73 \%$ and Hungary $72 \%$, compared to the EU average of $65 \%$ (Eurobarometer 2009). Hungarian sports research indicates that unfortunately there are no positive changes to be observed in participation sports in Hungary. Ifjuság 2008 research data show that the level of sports participation among the young has been dropping for several years. It can also be seen from the data that children start losing interest in sport at an earlier age each year. Consequently Hungarian participation sport is now crying out for help again.

\section{Conclusions and recommendations}

In comparing the British and Hungarian sports strategies we focused more on the differences than the similarities, inasmuch as these could explain the differences in their workings. In Britain, the performance in the 1996 Olympics was felt as a crushing defeat, whilst in Hungary the general crisis 
in sports pushed the country's leadership into thinking over the future management of sports, and to define targets and tasks. The planning of the British, then the English, sports strategy bore in mind that without involving the population in participation sports, elite sports could not be conducted successfully on a long-term basis. So, first of all, attention was focused on developing this area; they got right down to the roots and all levels and stakeholders were involved in the implementation process from the start. This ensured that everyone shared in the success: not only those involved in participation sports but also those who put huge efforts into school sports, the grass roots, competitive and elite sports. In Hungarian sports planning, the overlapping objectives of different areas result more in confrontation than cooperation. There is also a great need for an autonomous organisation to comprehensively direct the development of participation sports. It would help if the allocation of funds from financial sources could be overseen by this organisation. Its operation should be supported by sports policy decisions, but at the same time its results should be monitored and audited frequently. In our opinion, it is inconceivable that, without a detailed and affordable action plan tailored to specific social groups, there will be any significant progress towards efficiency in sport for the future. The current Hungarian practice of sports financing shows that the government's budget is being funded through a multi-channel system which often has institutions and organisations competing against each other. Not only does this increase the operating costs of sports institutions, but it also makes it difficult to set common goals for targeted funding. It would also be vital to invest more private funding into participation sports, which could happen on the one hand by encouraging companies with interests in leisure and sports to make the most of potential business opportunities, and on the other hand by stimulating employers to promote sport more. These ideas could be viable if participation sports organisations and leisure activity organisers collaborated with businesses in sponsorship. In addition, an important element - just like the English and British sports strategies - is to create a document containing a multi-stage, concrete action plan, which gets many stakeholders involved practically in the process of implementation.

As our closing thought, we would mention that the 2010 change of government might give a fresh boost to the achievement of the targets specified in the sports strategy. The most important signal was that sport was identified as a strategic sector by the new political leadership. Therefore, the National Sports Federation (NSSZ) ${ }^{20}$ and the allied voluntary sports organisations - with the National Leisure Sports Federation (NSZSZ) - have developed a 12-point plan for the long-term development of sport. This plan would primarily allocate responsibility for participation sports to local authorities, but the role of civil society is also emphasised. The slogan, "Let sport be your passion!", characterises the ambition of the public health improvement programme which is linked back to the earlier development. In this, the transformation of people's lifestyles and the stimulation of demand for regular exercise can play a crucial part. However, it needs to be stressed again that, having considered the economic opportunities and social situation, we do not believe the highly polarised Hungarian society can be 'attacked' with a single action plan because of its increasing inequalities. It is imperative to develop a strategic package by which different social groups - categorised on the basis of any demographic indicator - could be involved most effectively in participation sports. This is the only chance for Hungary to ever become a Sporting Nation.

\section{REFERENCES}

Audit Commission (2002). Sport and Recreation: Learning from audit, inspection and research, London: Audit Commission. Audit Commission (2006). Public sport and recreation services, National report. London: Audit Commission.

DCMS/Strategy Unit (2002). Game Plan: A strategy for delivering the Government's sport and physical activity objectives, London: Strategy Unit.

\footnotetext{
${ }^{20}$ The National Sports Federation (Nemzeti Sport Szövetség: NSSZ) is a governmental organisation for directing the development of sport in Hungary, established in 2001 by the "2000 CXLW Sport Law".
} 
Da Costa, L., Miragaya, A. (2002). Search of Experiences and Trends of Sport for All Worldwide. In L. Da Costa, A. Miragaya (Eds.), Worldwide Experiences and Trends in Sport for All (pp. 15-31). Aachen: Meyer und Meyer Verlag.

Downward, P., Dawson, A., Dejonghe, T. (2009). Sports Economics Theory, Evidence and Policy. Elsevier Ltd. Edginton, C., Coles, R., McClelland, M. (2003). Leisure Basic Concepts. Reston: VA AALR.

Földesiné, Sz. Gy., Gál, A. (2008). Választút előtt a sportpolitika. Magyar Sporttudományi Szemle, 2, 4-10.

Gallov, R. (2007). Sport XXI. Nemzeti Sportstratégia. Magyar Edzö, 3, 45-48.

Gáldi G. (2004). Szabadidőstruktúra és fizikai rekreáció Magyarországon 1963-20 00 között, életmód-időmérleg vizsgálatok tükrében. $\mathrm{PhD}$ értekezés, Semmelweis Egyetem Doktori Iskola.

Gratton, C., Taylor, P. (1991). Sport Participation in Britain: An investigation into the Changing Demand for Sport. Manchester: Polytechnic Working Paper.

Gratton, C., Taylor, P. (2000). Economics of Sport and Recreation. London: E. and F. N. Spon.

Háttéranyag a sport XXI. Nemzeti Sportstratégiájához (2005). A Nemzeti Sporttanács módosító javaslattételei után (átdolgozott háttéranyag).

Király, I. A. (2010). A szabadidösport szerepe az angol nemzeti sportstratégiában; a szabadidősport gazdaságtani elemzése. Szakdolgozat. Budapest: Semmelweis Egyetem Testnevelési és Sporttudományi Kar.

Kovács, T. A. (2007). A rekreáció kultúrája. Magyar Sporttudományi Szemle, 8, 30, 13-24.

Robinson, L. (2004). Managing public sport and leisure services. London: Routledge.

Sárközy, T. (2010). Sportjog, a 2004-es sporttörvény magyarázata (második, hatályosított kiadás). Budapest: HVG-ORAC Lap- és Könyvkiadó Kft.

Sport England (2004). The Framework for Sport in England. London:Sport England.

AUTHOR'S ADDRESS: $\quad$ Istvan Attila Kiraly

Semmelweis University Budapest

Faculty of Physical Education and Sport Sciences

1094 BudapestTúzoltó utca 37

Hungary

Email: kiralyist@yahoo.com 